TYPE: RESEARCH

\title{
National Law Development through Civil Procedure Law Reform as a Manifestation of State Goals during the Covid-19 Pandemic
}

\author{
Ahmad Habib Alfikry \\ Faculty of Law, Universitas Negeri Semarang, Semarang, Central Java, Indonesia \\ E-mail: alfikryahmadhabib@students.unnes.ac.id \\ ORCID Link: https://orcid.org/0000-0001-5597-7159 \\ Muhammad Riyan Afandi \\ Faculty of Law, Universitas Negeri Semarang, Semarang, Central Java, Indonesia \\ Dian Latifiani \\ Faculty of Law, Universitas Negeri Semarang, Semarang, Central Java, Indonesia
}

\section{Citation:}

Alfikry, A. H., Afandi, M. R., \& Latifiani, D. (2021). National Law Development through Civil Procedure Law Reform as a Manifestation of State Goals during the Covid-19 Pandemic. Lex Scientia Law Review, 5(2), 41-64, doi: https://doi.org/10.15294/lesrev.v5i2. 50483

\section{History of Article}

Received: October 01, 2021

Revised: November 07, 2021

Accepted: Noveber 19, 2021

(C) The Author(s)

\section{(c) (1) $\$$ ()}

This work is licensed under a Creative Commons Attribution-NonCommercialShareAlike 4.0 International License.

All writings published in this journal are personal views of the authors and do not represent the views of this journal and the author's affiliated institutions.

Lex Scientia Law Review published by Faculty of Law, Universitas Negeri Semarang, Indonesia in collaboration of UKM Lex Scientia. Published biannually every May and November.

LeSRev (Lex Scientia Law Review)

DOI: 10.15294/lesrev.v5i2.50483

\begin{abstract}
The purposes of this paper are: (i) to describe various problems in the philosophical, sociological and juridical aspects of the existence of civil procedural law as formal law in Indonesia; and (ii) offer solutions to these problems by updating the civil procedural law. The method in this paper uses normative legal research with a statutory approach by conducting a literature study using primary and secondary materials. The results of this paper indicate several things. The first, sociologically, people's lives develop dynamically so that the provisions of civil procedural law are not in accordance with the times. As for juridically, this provision is not unification, legal uncertainty, and a legal vacuum. The second, legal reform is part of the development of national law by taking into account the framework of the national legal system. The third, there are efforts and forms of civil procedural law reform carried out by each element of state power. The novelty of this paper is containing a comprehensive discourse that answers the problem of the applicability of civil procedural law with the efforts and forms of reform of
\end{abstract}


civil procedural law in Indonesia. The conclusion in this paper is the provisions of civil procedural law need to be updated based on philosophical, sociological, and juridical considerations. Reform of civil procedural law must take into account the national legal system, principles, and content material in its formation. Furthermore, the provisions provide a comprehensive scope. Such legal reform will be in line with national development because it embodies the values of justice and humanity so that the country's goals will be achieved

\section{KEYWORDS}

Civil Procedure Law; Reform; National Law Development

\section{INTRODUCTION}

State law discourse in Indonesia is confirmed in the state constitution as the 1945 Constitution of the Republic of Indonesia (hereinafter referred to as the 1945 Constitution of the Republic of Indonesia). Article 1 paragraph (3) of the 1945 Constitution of the Republic of Indonesia provides a depth of meaning that the administration of the Indonesian state is based on law as the highest authority. ${ }^{1}$ This means that the law in all its forms, types, and ways of maintaining is an important thing that the state has always held fast to regarding its validity. Legal classification according to how to defend is divided into 2, there are material law and formal law.2Interestingly, formal law is a legal provision that regulates how to implement and maintain material law. In the realm of legal science, civil procedural law includes formal law which, according to Sudikno Mertokusumo, is a formal law that guarantees compliance with material civil provisions with the presence of an intermediary judge. ${ }^{3}$ In this regard, Indonesian civil procedural law still uses Dutch heritage legal products such as the Herzien Indonesis Reglement (HIR) and Rechts Reglement Buitengeswesten (RBg). Both are still valid today based

\footnotetext{
1 Sayuti, Konsep Rechstaat Dalam Negara Hukum Indonesia (Kajian Terhadap Pendapat Azhari). Jurnal Kajian Ekonomi Islam dan Kemasyarakatan, Volume 4 Number 2, 2011.

2 Fence M. Wantu, Pengantar Ilmu Hukum, UNG Press, Gorontalo, 2015.

${ }^{3}$ Sudikno Mertokusumo, Hukum Acara Perdata Indonesia, Liberty, Yogyakarta, 2002, p. 2.
} 
on Article II of the Transitional Rules of the 1945 Constitution of the Republic of Indonesia. ${ }^{4}$

In its journey, civil procedural law in Indonesia is faced with dynamic sociological aspects. The life of the industrial revolution 4.0 and society 5.0 led to the current of massive development of social elements. ${ }^{5 T h i s}$ leads to progress in the multi-sectors of life such as business economics, technology, and socio-culture. This condition is relevant to the times that have spread to various parts of the world, including Indonesia. Law, which is an important aspect in the administration of the state, is expected to be responsive to the conditions and needs of society in this era of civilization. Civil law is an integral part that has a role to achieve the trinity of legal objectives (justice, certainty, and benefit) both in terms of material law and formal law. Contrast with what is expected at the beginning of this paragraph, that in fact civil procedural law has not been able to position itself to be said to be a responsive law.

Furthermore, at a pragmatic level, the problem becomes sustainable because Indonesia is also faced with a wave of the Covid-19 pandemic which emphasizes the state to be able to pay attention to the balance between aspects of justice in law enforcement and health. The data shows that as of October 1, 2021, there were civil cases, both general civil and special civil cases, that were submitted to the Semarang District Court with the following details:

Table 1. List Case in Semarang District Court

\begin{tabular}{|c|c|c|c|}
\hline \multicolumn{4}{|c|}{ Case List } \\
\hline General Civil & Amount & Special Civil & Amount \\
\hline Lawsuit Case & 5.116 & $\begin{array}{c}\text { Intellectual Property } \\
\text { Rights Case }\end{array}$ & 42 \\
\hline Small Claim Court Case & 266 & Bankruptcy Case & 378 \\
\hline $\begin{array}{c}\text { Cases of Resistance or } \\
\text { Repudiation (Derden Verzet) }\end{array}$ & 81 & $\begin{array}{c}\text { Industrial Relations } \\
\text { Court Case }\end{array}$ & 608 \\
\hline Application Case & 6359 & Total & 1.028 \\
\hline Total & 11.822 & & \\
\hline
\end{tabular}

Source: Information System for Searching Cases of the Semarang District Court. ${ }^{6}$

${ }^{4}$ Zil Aidi. Implementasi E-Court Dalam Mewujudkan Penyelesaian Perkara Perdata Yang Efektif dan Efisien. Jurnal Masalah-Masalah Hukum Universitas Diponegoro. (P-ISSN: 2086-2695, e-ISSN: 25274716).

5 Teguh G. Alam, Achmad L. N. Antony, et.al. Revolusi Industri Keempat: Akhir dari Buruh di Seluruh Dunia. Jurnal Hubungan Internasional, Number July 2, 2019.

6 Mahkamah Agung RI. Sistem Informasi Penelusuran Perkara Pengadilan Negeri Semarang. PNSemarang, October 1, 2021, accessed from di https://sipp.pn-semarangkota.go.id/. 
The data shows that there are many civil cases that go to the Semarang District Court and must be resolved even though law enforcement officers are still faced with the challenges of the COVID-19 pandemic. In this case, it increases the pressure again in the realm of law enforcement. Moreover, the provisions of civil procedural law where there are still many gaps to enter into the complex problematic space.

Such a legal situation indicates the need to revamp the provisions of civil procedural law in Indonesia. The length of this discussion is nothing but to enter into the conception of national law development. This conception leads to the goals of the Indonesian state as described in the fourth paragraph of the Preamble to the 1945 Constitution of the Republic of Indonesia. The legal basis for development planning refers to The Law Number 25 of 2004 concerning the National Development Planning System. ${ }^{7}$ and The Law Number 17 of 2007 concerning the National Long-Term Development Plan for 2005-2025. ${ }^{8}$

\section{METHOD}

The author uses a normative juridical research method, the approach to legislation by examining the relevant legislation and related to existing legal issues. ${ }^{9}$ Then, in this writing, the author conducts a literature study using primary and secondary materials including legislation, books, journal articles, and online publications.

\section{RESULTS AND DISCUSSION}

\section{A. The Existence of Civil Procedure Law in Indonesia}

Sjachran Basah in his book entitled argues that procedural law is an element of justice which in this case also includes material law. According to him, the judiciary (rechtspraak) relating to the state's duty in enforcing the law will be paralyzed if there is no material law. It becomes a necessity because it will reach the point of not knowing what will be embodied. In other applies case, that the judiciary will be ferine if it is not accompanied by formal law because of the unclear limits of authority. ${ }^{10}$ This leads to the existence of civil procedural law in Indonesia. Theoretically, its existence in the national legal

\footnotetext{
7 Republic of Indonesia, Law Number 25 of 2004 concerning the National Development Planning System.

${ }^{8}$ Republic of Indonesia, Law Number 17 of 2007 concerning the National Long-Term Development Plan of 2005-2025.

9 Peter Mahmud Marzuki, Penelitian Hukum, Kencana, Jakarta, 2011, p. 93.

${ }^{10}$ Sjachran Basah, Hukum Acara Pengadilan Dalam Lingkungan Peradilan Administrasi (HAPLA), Rajawali Pers, Jakarta, 1989, p. 1.
} 
system, civil procedural law is formal law ${ }^{11}$ with its important position in enforcing material law (civil law). This explanation leads to a conclusion that these two provisions (formal and material civil) have a strong relationship like two sides of a coin.

The division of law according to its contents which consists of private law and public law forms a specific space regarding the contents of its provisions, so that this will be converging on the purpose of each legal classification. Civil procedural law is part of private law that regulates individual relationships and interests, including the settlement of disputes in court, this definition is the Wirjono Prodjodikoro's thought. ${ }^{12}$ Civil procedural law has big aspirations for the face of law in Indonesia because it is a guarantee of compliance with civil law so that it can restore a person's rights (losses) through a judge's decision. ${ }^{13}$ However, over time (after Indonesia's independence), civil procedural law is no longer a great hope to achieve legal goals. In the era of civilization with all the current technological and social developments, Indonesia still uses legal products (civil procedural law) inherited from the Netherlands such as HIR and RBg. It can be explained that HIR is a civil procedural law applicable in Java and Madura. Unlike HIR, RBg is a civil procedural law that applies in areas outside Java and Madura.

Historically, the term HIR started with the name Indlandsch Reglement (IR) which means Reglemen Bumiputera. It was drafted by Wichers as President of the Hooggerechtschof or the Supreme Court in Indonesia at that time. The regulation was drafted by him based on the Governor General Rochussen's Decree No 3 of $1846 .{ }^{14}$ The draft went through a long journey with objections that resulted in changes and improvements, until there was a crucial article of HIR. It is an article 393. On April 5, 1848, St. 1848-16 published and entered into force on May 1, 1848 known as IR. The enactment of Article 393 of the HIR concludes that: (i) Judges have an obligation to find a solution through establishing procedures as required at the practical level. In this case, there is an expansion of the procedural regulations with the judge's decision; (ii) HIR is a formal law as a tool that implements material law. ${ }^{15}$

In addition to HIR, there are also RBg that are present as a guarantee of legal certainty for events outside Java and Madura. The provisions that

${ }^{11}$ Sinta Noer Hudawati, Problematika Hukum Formil Penyelesaian Sengketa Ekonomi Syariah di Pengadilan Agama, Jurnal Penegakan Hukum dan Keadilan Volume 1 Number 1 March 2020, p. 29.

${ }_{12}$ Wirjono Prodjodikoro, Hukum Acara Perdata di Indonesia, Sumur Bandung, Bandung, 1975,p. 13.

${ }_{13}$ Dian Latifiani, Permasalahan Pelaksanaan Putusan Hakim, Jurnal HAPER Volume 1 Number 1 2015, p. 16.

${ }^{14}$ Supomo, Hukum Acara Perdata Pengadilan Negeri, Pradnya Paramita, Jakarta, 1985, p. 5

${ }^{15} \mathrm{Ibid}$ 
basically already existed in this IR since 1927 with Stb. 1927-227. The establishment of the RBg adds to the types of procedural law regulations in the Dutch East Indies, as follow as: (i) Reglement op de Burgerlijke Rechtsvordering voor Europeanen (Rv) which applies to European groups; (ii) IR that undergoes a change is referred to as HIR; and (iii) RBg. In subsequent legal developments, there are other civil procedural law regulations that still scattered or pluralistic, such as: (i) Burgerlijke Wetboek (BW) in Book IV on Evidence and Expiration; (ii) Law on Marriage; (iii) Supreme Court Act; (iv) the General Courts Act; (v) Judicial Powers Act; and others. ${ }^{16}$

\section{B. Development of National Law by Observing the Framework of the National Legal System}

As a sovereign country, Indonesia has a state goal as described in the fourth paragraph of the Preamble to the 1945 Constitution of the Republic of Indonesia. The aim of the state is in a straight line that leading to general welfare. ${ }^{17}$ In achieving this, it requires planning, efforts, and processes that are inherent in the conception of national development. This conception, normatively refers to Law No. 25 of 2004. Article 1 point 2 of the a quo law basically explains that national development is an effort of the nation's components to achieve the goals of the state. ${ }^{18}$ Regarding this matter, it cannot be separated from the scope of the planning which according to Article 3 paragraph (3) of the a quo law is divided into: (i) long-term development plan (RPJP); (ii) the medium term development plan (RPJM); and (iii) annual development plans. ${ }^{19}$

Digging deeper into the RPJM, there are 4 pillars of the RPJMN IV in 2020-2024, one of which is a solid political and legal institution. The 7 development agendas of the RPJMN are strengthening the stability of Polhukhankam and the transformation of public services. In this agenda, the state is obliged to attend based on its objectives, provide high quality public

${ }^{16}$ Halida Zia, Mario Agusta, and Desy Afriyanti. Pengetahuan Hukum Tentang Hukum Acara Perdata. Rio Law Jurnal, Volume 1 Number 2, 2020. Referred to Dewa Nyoman Rai A P, Asas Integrasi Dalam Undang-Undang Kepailitan Versus Cita-Cita Kodifikasi Dan Unifikasi Hukum Acara Perdata, Jurnal Hukum Acara Perdata,Volume 4 Number 2018.

${ }^{17}$ Nina Martiana, Badan Pemeriksa Keuangan dan Kesejahteraan Rakyat. Jurnal Ilmiah Akuntansi Indonesia, Volume 3 Number 2 October 2018, p. 1.

${ }_{18}^{18}$ Op.Cit.

${ }^{19}$ Ibid. 
services, and enforce state sovereignty. ${ }^{20}$ This RPJMN IV is based on Presidential Regulation Number 18 of $2020 . .^{21}$

In the above agenda, there are priority programs (PP) such as law enforcement in the context of legal development. The priority programs are then divided into priority activities such as: 22

1) Regulatory Arrangement

a) Establishment of a Regulatory Management Agency; and

b) Renewal of Legal Substance.

2) Improvement of the Criminal and Civil Law System

a) Improvement of economic law to support ease of doing business;

b) Application of a restorative justice approach; and

c) IT support in the field of law and justice.

3) Strengthening the Anti-Corruption System

a) Strengthening the implementation of the national strategy to prevent corruption; and

b) Optimization of asset recovery and management mechanisms.

4) Improved access to justice

a) Strengthening justice services; and

b) Empowerment of law for the community.

The national law development agenda as described above stems from the existence of unresolved strategic legal issues and problems. This starts from disharmony, inconsistent, overlapping, multiple interpretations, and scattered in all kinds of laws and regulations. ${ }^{23}$ So in this case, it is necessary to pay attention to the nature of the legal system as a determinant of the effectiveness of the passage of law and the achievement of legal objectives. ${ }^{24}$ Lawrence Friedman argues that the legal system is a legal entity with 3 aspects: (i) legal structure; (ii) legal substance; (iii) and legal culture. ${ }^{25}$

\footnotetext{
${ }^{20}$ Ministry of National Development Planning/Bappenas, Technocratic Draft of National Medium-Term Development Plan 2020-2024, Ministry of National Development Planning/Bappenas, Jakarta, 2019, p. 2-6.

${ }^{21}$ Republic of Indonesia, Presidential Regulation Number 18 of 2020 concerning the National Medium-Term Development Plan for 2020-2024.

${ }^{22}$ Attachment to Presidential Regulation Number 18 of 2020 concerning the 2020-2024 National MidTerm Development Plan.

${ }^{23}$ Ministry of National Development Planning/Bappenas, Op. cit.p. 220.

${ }^{24} \mathrm{Abd}$. Rahman and Heriyanto, Memasyarakatkan Hukum: Pembaharuan Hukum Yang Dinamis Guna Mewujudkan Efektivitas Penegakan Hukum Yang Berkeadilan HUKMY Legal Journal, Volume 1 Number 1, 2021.

${ }^{25}$ Lawrence Friedman, The Legal System, Asocial Science Perspective, Russell Sage Foundation, New York, 1975.
} 
The legal system which consists of 3 aspects as mentioned above are interrelated with each other. Weak or bad one aspect in the legal system, it will have a major influence on the passage of the law. These weaknesses will cause a limp or even the collapse of the pillars of the legal building so that the legal objectives cannot be achieved. Friedman gives different meanings about these three aspects.The first, the legal structure is an aspect related to law enforcement officers (APH). ${ }^{26}$ The second, regarding the content of principles, norms, legal rules in written or unwritten form, and in this case also including court decisions, Friedman argues that this is the meaning of legal substance. The third, legal culture is the habit of the people who co-operate with law enforcement. ${ }^{27}$

National development in the field of law seems to pay attention to 3 aspects of the legal system. This can be seen from the agenda and priority programs in the RPJMN IV. The agenda for strengthening the anti-corruption system and program for strengthening justice services is inherent in aspects of the legal structure. Regarding the aspect of legal substance, there is a regulatory arrangement through the renewal of legal substance. Aspects of legal culture in the legal empowerment agenda for the community.

\section{The Urgency of Civil Procedure Law Reform}

In this discussion, the author focuses on the legal substance aspect in the national law development agenda. In this agenda, it is stated that there are priority law enforcement programs, one of which is the renewal of legal substance which consists of: (i) Draft Law (hereinafter referred to as Bill) Criminal Code (KUHP)/Book of Procedural Law Criminal Code (KUHAP); (ii) the Civil Procedure Code; (iii) the Business Entity Bill; (iv) the Fiduciary Guarantee Bill; and (v) Bankruptcy Bill..$^{28}$

The inclusion of the Civil Procedure Law Bill in the priority project for legal substance reform raises questions about its urgency. Three foundations in the formation of law are clear answers to these questions. These are philosophical, sociological, and juridical basis. These three foundations become material to be considered in the formation of law. ${ }^{29}$ The philosophical

${ }^{26}$ Lutfil Ansori, Reformasi Penegakan Hukum Perspektif Hukum Progresif, Jurnal Yuridis, Volume 4 Number 2, 2017, p. 150.

27 Sudjana, Penerapan Sistem Hukum Menurut Lawrence W Friedman Terhadap Efektivitas Perlindungan Desain Tata Letak Sirkuit Terpadu Berdasarkan Undang-Undang Nomor 32 Tahun 2000, Jurnal Hukum Ekonomi Syariah, Volume 2 Number 1, 2019.

${ }^{28}$ Appendix, Op.Cit

29 Taufik H Simatupang, Mendudukkan Konsep Executive Review Dalam Sistem Hukum Ketatanegaraan Indonesia. Jurnal Penelitian Hukum De Jure, Volume 19 Number 2, 2019, p. 219. 
foundation is a rule or legal provision that reflects the values in society. The sociological basis related to the enactment of regulations is not only a coercion from the institution authorized to make it, but also the acceptance of the community. This juridical basis shows the relevance of both the form and type of legislation with regulations that are hierarchically higher. ${ }^{30}$

The three foundations that were taken into consideration in the preparation of the Civil Procedure Code are as follows:

1) Philosophical Foundation

As an independent country, Indonesia has goals that are in line with the theorywelfare state or for the general welfare. To achieve this noble goal, the state must be able to move dynamically with the existence of national development, one of which is in the field of law which in its formation has the role of legal politics in it. ${ }^{31}$ Laws that arise from social phenomena in society because of the many interests between individuals, exist to regulate in order to achieve order. ${ }^{32}$ The number of human interests that are united in the same environment will trigger conflicts or disputes. This is then coherent with the existence of a dispute resolution process, both private and public law. The estuary is an understanding of the existence of formal legal provisions as guarantees and material law enforcement.

A principle that is always used as a basis in theoretical and practical law is the principle of fast, simple, and low-cost justice. Normatively, this principle is regulated in Article 2 paragraph (4) and Article 4 paragraph (2) of the Law on Judicial Power. This principle is certainly related to the ultimate goal of law enforcement, well known as justice. ${ }^{33}$ However, this when juxtaposed with the facts, reflects a contradictory thing. That in the process of litigation that occurs it is not

${ }^{30}$ Imam Syaukani and A Ahsin Thohari, Dasar-Dasar Politik Hukum, Raja Grafindo Persada, Jakarta, 2006, p. 53.

31 Mia Kusuma Fitriana, Peranan Politik Hukum Dalam Pembentukan Peraturan PerundangUndangan di Indonesia Sebagai Sarana Mewujudkan Tujuan Negara, Jurnal Legislasi Indonesia, Volume 12 Number 2, 2015.

${ }^{32}$ Sudikno Mertokusumo, Pengantar Ilmu Hukum, Liberty, Permadi Purbacaraka, Yogyakarta. Lihat juga di Muhammad Ridwansyah, Mewujudkan Keadilan, Kepastian, dan Kemanfaatan Hukum dalam Qanun Bendera dan Lambang Aceh, Jurnal Konstitusi, Volume 13 Number 2, 2016.

${ }^{33}$ Syprianus Aristeus, Eksekusi Ideal Perkara Perdata Berdasarkan Asas Keadilan Korelasinya Dalam Upaya Mewujudkan Peradilan Sederhana, Cepat, dan Biaya Ringan, Jurnal Penelitian Hukum De Jure, Volume 20, Number 3, 2020. 
fast, less efficient, and expensive in terms of cost. ${ }^{34}$ This certainly takes away the value of justice that should be obtained by justice seekers.

Moreover, the provisions of Indonesian civil procedural law, which still use Dutch legal products as described above, are no longer relevant to the way of life of the Indonesian people whose preference is to achieve state goals. This can be seen from cases that go to court rejected by judges because there are things that are not regulated in the main guidelines of civil procedural law. These are HIR and RBg. The implication is that justice seekers do not get their rights.

As for legal coherence and state goals, the ideal (philosophical) value in civil procedural law is justice. The value of justice is at the heart of legislation so that it becomes the main goal to always be glorified and enforced in law enforcement ${ }^{35}$ so that people get their rights. The provisions of such civil procedural law will also be in accordance with the spirit of the nation which is in line with Carl von Savigny's opinion, which is a necessity regarding the compatibility between law and the spirit of the nation. ${ }^{36}$

2) Sociological Foundation

The world is currently in an era of civilization marked by advances in information technology. A major revolution that was planned and communicated by the German Government in 2011, was industry 4.0. The focus of this change is to strengthen competitiveness through a high-tech strategy. ${ }^{37}$ Industry 4.0 is characterized by: (i) realtime networking; (ii) intelligent and digital in terms of equipment, objects and people on industrial management. ${ }^{38}$

The changes above require humans as role holders in life to be able to be adaptive, responsive, and innovative. This then leads to a situation where there is an identification of the elements that make up a knowledge-intensive society. This is known as society 5.0. Social innovation is inherent in it, with 3 elements that drive humans to the

34 Yue Guan dan Eni Oktaviani, Meningkatkan Efisiensi Peradilan Dalam Tata Cara Prosedural Litigasi Perdata Indonesia, Jurnal Ilmu Hukum, Volume 6 Number 2, 2021.

${ }^{35}$ Iin Ratna Sumirat, Penegakan Hukum dan Keadilan Dalam Bingkai Moralitas, Jurnal Hukum dan Politik Al Qisthas, Volume 11 Number 2, 2020.

${ }^{36}$ Bernard L. Tanya, Teori Hukum, Cetakan Ketiga, Genta Publishing, 2012, p. 119.

${ }^{37}$ M. Hermann, T. Pentek, B. Otto, Design Principles for Industry 4.0 Scenarios, $4^{\text {th }}$ Hawaii International Conference on System Sciences, 2016.

${ }^{38}$ U. Dombrowski, T. Richter, P. Krenkel, Interdependencies of Industrie 4.0 \& Lean Production Systems - a use case analysis, 27th International Conference on Flexible Automation and Intelligent Manufacturing, FAIM2017, Italy, 2017. 
world of progress, such as elements of data, information, and knowledge. ${ }^{39}$ Society 5.0 has a focus on placing humans at the center of technology and innovation to provide humanitarian benefits. ${ }^{40}$ This social revolution is considered as a peaceful change with the aim of improving the welfare of the people so as to obtain a good quality of life as echoed by Japan as the first country to construct this. ${ }^{41}$

Industry 4.0 and Society 5.0 provide an overview of the world situation and society which is an entity in it experiencing massive development. This certainly affects the multi-sector of life such as technology, business economics, social, and law. It is undeniable that each of these fields has an attachment to one another so that with this concept it is the hope of many countries to be able to solve the problematic things experienced by the country.

It can be said that the two concepts above are in line with national development which is divided into several areas of life, including law. Law is often considered as something that cannot go hand in hand with the development of society. ${ }^{42}$ Complicated when there are several provisions in legal sources that still use colonial products that are unable to answer and provide solutions in the process of resolving disputes or cases. This is a big problem because it can hinder law enforcement in obtaining humane justice for the people.

In addition, there are other things that are quite hindering the implementation of law enforcement in Indonesia at this time. It is the vicious virus covid-19.43 The presence of this virus has an impact on the life of the country. Health, which contains elements of human rights, is an aspect that is always pressed to be balanced with other aspects of life in the era of the COVID-19 pandemic. In the realm of law, for example, in the process of law enforcement (proceedings) must pay attention to aspects of individual health. Law enforcement is then faced with

${ }^{39}$ Hitachi-Utokyo Laboratory, Society 5.0 A People-centric Super-smart Society, Hitachi and The University of Tokyo, Tokyo, p. 10.

${ }^{40}$ Andreia G. Pereira, Tania M. Lima, dan Fernando Charrua Santos, Industry 4.0 and Society 5.0: Opportunities and Threats, International Journal of Recent Technology and Engineering (IJRTE) ISSN: 2277-3878, Volume 8 Issue 5, 2020.

${ }^{41}$ C. M. Ferreira, S. Serpa, Society 5.0 and Social Development Contribution to a Discussion, Sciedu Press, Volume 5, 2018, p. 26-31.

${ }^{42}$ Enju Juanda, Penalaran Hukum (Legal Reasoning), Jurnal Universitas Galuh, Volume 5 Number 1, 2017.

${ }^{43}$ Suriani dan Ismail, Pengaruh Pandemi Covid-19 Terhadap Pelaksanaan Persidangan Perkara Pidana di Pengadilan, Prosiding Seminar Nasional Multidisiplin Ilmu Universitas Asahan ke-4 Tahun 2020. 
problems because the current legal provisions do not regulate this matter. Meanwhile, during the COVID-19 pandemic, cases that go to court are still ongoing. A state consisting of 3 power institutions (Executive, Legislative, and Judiciary) ${ }^{44}$ must be present to solve this problem through national development in the field of law by reforming civil procedural law. This update can adapt to the development of the existing community by adopting the 2 major concepts above (Industry 4.0 and Society 5.0) so that the law can be said to be responsive. This is because development and legal reform are basically closely related to society. ${ }^{45}$ Such a law is expected to be able to resolve civil cases effectively and efficiently so that the trinity of legal objectives can be achieved.

3) Juridical Platform

The introduction to this juridical basis is to reiterate the sources of plural civil procedural law. In addition to still using the provisions of colonial inheritance law, civil procedural law also has other legal provisions as mentioned in the final section of the sub-discussion on the existence of civil procedural law in Indonesia in this writing. Therefore, to the many regulations, the provisions of civil procedural law are also scattered in several regulations. ${ }^{46}$ This very plural law invites multiple interpretations and requires judges to play a role in interpreting in adjudicating cases. The implication is the denial of the principle of simple, fast, and low-cost justice. This can happen due to unclear regulations causing the event process to be convoluted ${ }^{47}$ and the occurrence of multi-interpretation will require the event process in a long time. This juridical condition then became a consideration for the establishment of the Civil Procedure Code.

\section{Efforts and Forms of Reform of Civil Procedure Law in Indonesia}

National development in the field of law is not a new thing in Indonesia. The noble ideals and goals of the state for the welfare of the people

${ }^{44}$ Luthfi Widagdo Eddyono, Penyelesaian Sengketa Kewenangan Lembaga Negara oleh Mahkamah Konstitusi, Jurnal Konstitusi, Volume 7 Number 3, 2010.

${ }^{45}$ Dian Latifiani, Human Attitude and Technology: Analyzing a Legal Culture on Electronic Court System in Indonesia (Case of Religious Court), Journal of Indonesian Legal Studies, Volume 6 Issue 1, 2021.

46 I Ketut Tjukup Nyoman, A. Martiana, et.al, Penerapan Teori Hukum Pembangunan Dalam Mewujudkan Peradilan Sederhana, Cepat, dan Biaya Murah. Jurnal Hukum Acara Perdata ADHAPER, Volume 1 Number 1, 2015.

${ }^{47}$ Ibid. 
require the state to run dynamically following the times. The implementation of the state based on law, leading to this field (law) has always been a common concern from its formation to its implementation. Moreover, if loopholes are found in the legal provisions, it is necessary to make changes, additions, or even updates.

Civil procedural law reform has been a long-standing discourse. Can be pulled back to see the history that shows the civil procedural law reform efforts. Along the way, there are concepts that have been formulated regarding the provisions of the Civil Procedure Code but have not been ratified as law. ${ }^{48}$ The provisions in question are explained in the following chart:

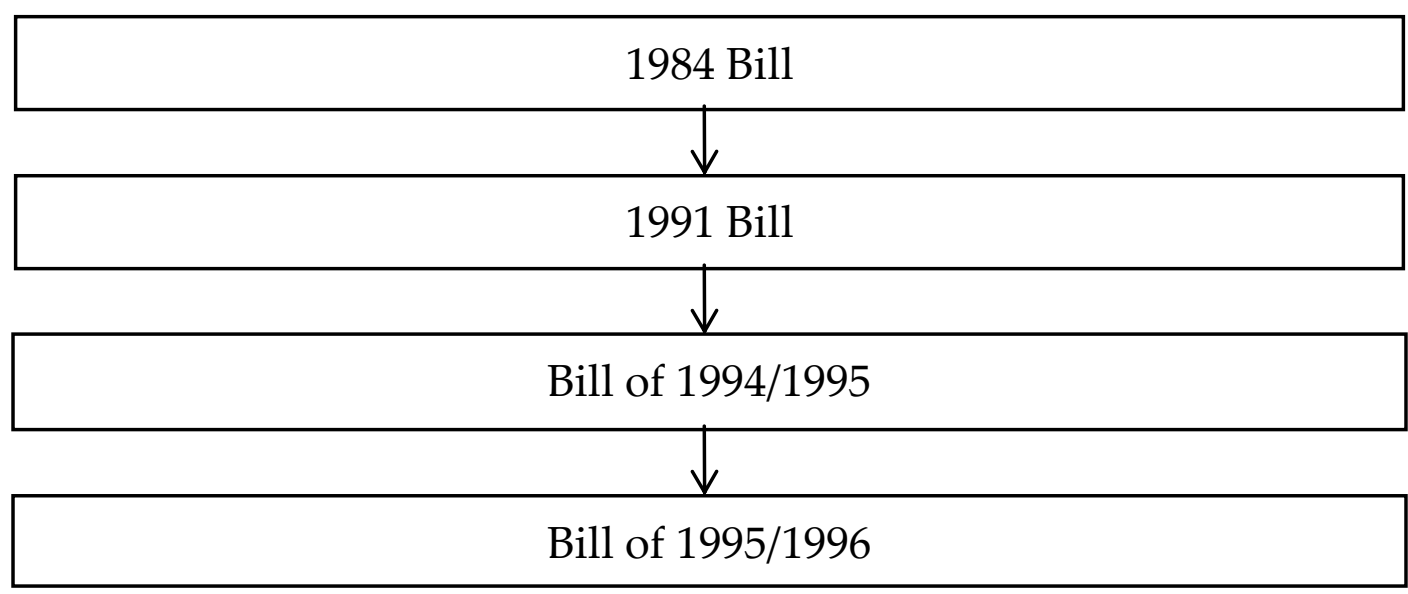

The following is a table of efforts to develop civil procedural law in the era of Joko Widodo's administration:

Table 2. Development of the Civil Procedure Code in the RPJMN

\begin{tabular}{|c|l|l|}
\hline Regarding & $\begin{array}{c}\text { RPJMN 2015-2019 } \\
\text { (In Presidential } \\
\text { Regulation Number } 2 \text { of } \\
\text { 2015) }\end{array}$ & $\begin{array}{c}\text { RPJMN 2020-2025 (In } \\
\text { Presidential Regulation } \\
\text { Number 18 of 2020) }\end{array}$ \\
\hline Target & $\begin{array}{l}\text { The realization of a civil } \\
\text { law system is easy and } \\
\text { fast }\end{array}$ & $\begin{array}{l}\text { Improvement of the civil } \\
\text { law system }\end{array}$ \\
\hline $\begin{array}{c}\text { Legal } \\
\text { Regulatory }\end{array}$ & $\begin{array}{l}\text { Civil Procedure Law Bill } \\
\text { (in the 2019 priority }\end{array}$ & $\begin{array}{l}\text { Civil Procedure Law Bill } \\
\text { (in the 2021 priority }\end{array}$ \\
\hline
\end{tabular}

48 Faisal Luqman Hakim, Simplikasi Prosedur dengan Pemanfaatan Teknologi dalam Rancangan Undang-Undang Hukum Acara Perdata, Jurnal Hukum Acara Perdata (Adhaper), Volume 5 Number 1, 2019.

${ }^{49}$ Republic of Indonesia, Presidential Regulation Number 2 of 2015 concerning the 2015-2019 National Medium-Term Development Plan.

50 Op.Cit, Presidential Regulation Number 18 of 2020. 


\begin{tabular}{|c|c|c|}
\hline Framework & $\begin{array}{l}\text { national legislation } \\
\text { program based on the } \\
\text { Decree of the Indonesian } \\
\text { House of Representatives } \\
\text { Number 19/DPR } \\
\text { RI/I/2018-2019) }\end{array}$ & $\begin{array}{l}\text { national legislation } \\
\text { program based on the } \\
\text { Decree of the Indonesian } \\
\text { House of Representatives } \\
\text { Number } 1 / \mathrm{DPR} \\
\text { RI/IV/2020-2021) }\end{array}$ \\
\hline
\end{tabular}

Source: Author's Data Based on Related Regulations.

The Civil Procedure Code has not yet been ratified, requiring law enforcement elements to be able to fill legal voids through legal reform. The Supreme Court as one of the actors of judicial power tries to overcome legal problems by forming regulations that are in accordance with the development of society. This is deemed necessary because: (i) civil procedural law upholds the principles of a simple, fast, low cost trial; (ii) in addition to developments, there are problems and community needs in law enforcement that is just and humane in the era of the covid-19 pandemic; and (iii) the provisions of civil procedural law such as HIR and RBg which have many shortcomings by not regulating several matters relating to the procedural process. As a result of this, the judge uses other sources of law such as: (i) Regulation of the Supreme Court of the Republic of Indonesia; (ii) Circular Letter of the Supreme Court of the Republic of Indonesia; (iii) Jurisprudence; and (iv) Doctrine..$^{53}$

The forms of renewal of civil procedural law in Indonesia to date are as follows:

1) Supreme Court Regulation

a) Regulation of the Supreme Court Number 1 of 2002 concerning Procedures for Lawsuits for Group Representatives;

This Supreme Court regulation was made because the provisions of the civil procedural law of HIR and RBg have not regulated the Class Representative Lawsuit. This has led to the frequent rejection of lawsuits by judges submitted in group representatives. This regulation regulates starting from: (i) general

${ }^{51}$ Republic of Indonesia, Decree of the House of Representatives of the Republic of Indonesia Number 19/DPR RI/I/2018-2019 concerning the National Legislation Program for the 2019 Priority Bill and Amendments to the National Legislation Program for the 2015-2019 Draft Law.

${ }^{52}$ Republic of Indonesia, Decree of the House of Representatives of the Republic of Indonesia Number 1/DPR RI/IV/2020-2021 concerning the National Legislation Program for the 2021 Priority Laws and the National Legislation Program for the Amendment Laws for 2020-2024.

${ }^{53}$ Mohammad Kamil Ardiansyah, Pembaruan Hukum Oleh Mahkamah Agung Dalam Mengisi Kekosongan Hukum Acara Perdata di Indonesia, Jurnal Ilmiah Kebijakan Hukum, Volume 14 Number 2, 2020, p. 369. 
provisions, (ii) procedures for class action requirements, (iii) exit statements, (iv) notices, and (v) closing provisions. ${ }^{54}$

b) Regulation of the Supreme Court Number 2 of 2015 jo. Regulation of the Supreme Court Number 4 of 2019 concerning Small Claim Court;

The development of society related to business, economic, and civil legal relations requires a simpler and faster settlement of cases. In response to such conditions, this Supreme Court Regulation was formed. As for the things that are regulated are general provisions which in the amendment of Article 1 number 1 in the latest regulation explains that this simple civil lawsuit, the value of the material claim is a maximum of IDR 500,000,000 which is then settled through simple procedures and evidence. In addition, it also regulates the authority to judge; scope; and the parties, procedural law and stages of settlement of small claim court, examination of small claim court, court decisions and minutes, legal remedies, implementation of decisions, transitional provisions, and closing provisions. ${ }^{55}$

c) Supreme Court Regulation Number 1 of 2019 concerning Electronic Case Administration and Trial.

This Supreme Court regulation is a form of regulation that responds to the demands of the development of the world of technology and the intellectual community so as to present provisions that are in line with this. Through this regulation, an effective and efficient administration and court service system can be achieved. Consists of 8 Chapters which regulate: (i) general provisions; (ii) users of electronic case administration services; (iii) administration of electronic case registration and payment; (iv) electronic calls and notifications; (v) electronic trial; (vi) electronic case administration; (vii) transitional provisions; and (viii) transitional provisions. ${ }^{56}$

2) Supreme Court Circular

a) Circular Letter of the Supreme Court Number 1 of 2020 concerning Guidelines for the Implementation of Duties During the Prevention

\footnotetext{
${ }^{54}$ Republic of Indonesia, Regulation of the Supreme Court Number 1 of 2002 concerning Class Action Lawsuits.

${ }^{55}$ Republic of Indonesia, Regulation of the Supreme Court Number 2 of 2015 jo. Supreme Court Regulation Number 4 of 2019 concerning Small Claim Court.

${ }^{56}$ Republic of Indonesia, Supreme Court Regulation Number 1 of 2019 concerning Electronic Case Administration and Trial.
} 
of the Spread of Corona Virus Disease 2019 (COVID-19) within the Supreme Court and Judicial Bodies Under it.

When various countries are faced with a wave of covid-19 which affects all areas of life including the law. Such a situation requires law enforcement elements to play a full role in dealing with major problems. Health is something that must be considered, while the law enforcement process must also continue to be carried out. Equilibrium is made and the entry into force of this circular. The goal is to keep both things running well.

\section{E. Directions for Reforming the Civil Procedure Code as a Manifestation of Indonesia's State Goals}

Pancasila as staatfundamentalnorm ${ }^{57}$ and the source of all sources of law ${ }^{58}$ contains the values and fundamental rules used in achieving the goals of the state. The content is in harmony with the soul and views of the nation ${ }^{59}$ make Pancasila as a strong state ideology to be used as a basis in the administration of the state. The fundamental values in each of the Pancasila precepts are holistic and in line with the momentum to realize the goals of the Indonesian state.

Diving deeper, the law that extensively regulates many things in the life of the state, in essence has the same goal as the state's goal, is justice. This value is also explicitly contained in Pancasila, precisely in the 2nd Precept. The justice referred to in this case is justice which is inherent in human values. These two values are essential, considering that in the legal exponentalthough it will not be separated from both. Gustav Radbruch suggests that there are 3 values that influence the achievement of legal objectives, as follow as: (i) justice; (ii) benefit; and (iii) certainty. ${ }^{60}$ Radbruch argues that the law is the bearer of justice, justice in this case when parsed has a normative and constitutive nature. Normative can mean that the law stems from justice. As for constitutive, in the law there must be an absolute element, is justice. Without it, the law will not gain merit. ${ }^{61}$

${ }^{57}$ Gunawan A Tauda, Pemaknaan Pancasila Sebagai Norma Fundamental Negara, Jurnal Penelitian Humano, Volume 9 Number 2, 2018.

58 Fais Yonas Bo'a, Pancasila Sebagai Sumber Hukum dalam Sistem Hukum Nasional, Jurnal Konstitusi, Volume 15 Number 1, 2018.

${ }^{59}$ Yuniwati, Politik Hukum dalam Kesejahteraan Rakyat, Jurnal Justicia Sains, Volume 2 Number 2, 2017.

${ }^{60}$ Muhammad Erwin, Filsafat Hukum, Raja Grafindo, Jakarta, 2012, p. 123.

${ }^{61}$ Bernard L Tanya, et al., Teori Hukum: Strategi Tertib Manusia Lintas Ruang dan Generasi, Genta Publising, Yogyakarta, 2013, p. 117. 
The essence of legal justice is the content of human values. This value will always be inherent in humans which then places it on the concept of dignity and worth. The breath of humanism will come into contact with the fundamental rights that humans have from birth and are universal, is human rights. In the smallest part of the exponent of human rights, there are types such as civil and political rights, socio-cultural rights, and economic rights. ${ }^{6}$ Human rights become an important discourse for the rule of law to be guaranteed, protected, and fulfilled. It shows the relationship between law, justice, and humanity. That the direction of the formation and renewal of positive law is based on justice and humanity as a manifestation of the state's goals.

The complexity of the problematic legal substance in positive law is the impetus for making improvements in the development of national law. Legal reform is a bright way to achieve state goals, especially in the field of law that is just and humane.Likewise with civil procedural law. The existence of gaps and other problems from the sociological and juridical aspects enlarge the dialectical space for reform. Not without reason, when justice which is the basic value and purpose of the law itself has been taken away, at that time the law is no longer in its dignity.

The directions for reforming civil procedural law are: (i) the addition of norms or reaffirmation of existing provisions; and (ii) The enactment of this new civil procedural law closes the space for the substance of the provisions of the civil procedural law to be regulated outside of the new provisions. So that the target of civil procedural law reform is a unification codification. Meanwhile, in terms of its formation, it takes into account the 3 foundations as mentioned above. There are philosophical, sociological, and juridical. In addition, it must also refer to Law Number 12 of 2011 which regulates starting from the principle of the formation of laws and regulations in Article 5; its content reflects the principles in Article 6; and the civil procedural law must also contain the content referred to in Article 10.63

As for the scope of the regulation of civil procedural law as follows: ${ }^{64}$

1) Claims for rights which include lawsuits and applications, registration, determination of court days, and summons;

2) Granting special powers;

${ }^{62}$ Eko Hidayat, Perlindungan Hak Asasi Manusia Dalam Negara Hukum Indonesia, Jurnal Hukum Ekonomi Syariah, Volume 8, Number 2, 2016.

${ }^{63}$ Republic of Indonesia, Law Number 12 of 2011 concerning the Establishment of Legislation.

${ }_{64}$ R. Benny Riyanto, Materi Diskusi Publik Pembaharuan Hukum Acara Perdata Indonesia, Badan Pembinaan Hukum Nasional Kementerian Hukum dan Hak Asasi Manusia. 
3) Court powers are both absolute and relative;

4) Resignation and right of denial;

5) Efforts to guarantee rights;

6) Examination in court which consists of ordinary events, short events, and quick events;

7) Evidence includes confessions, letters, testimonies, suspicions, oaths, local examinations, and experts;

8) Decision;

9) Legal remedies which are divided into appeal, cassation, and judicial review; and

10) The implementation of court decisions includes execution of decisions, debt recognition, and taking hostages.

This direction of civil procedural law reform contains comprehensive content material which is then present to overcome the complexity of the existing formal legal problems. This is because this update is in accordance with the 3 foundations under consideration. The first, philosophically, the renewal of civil procedural law is in accordance with the philosophy and spirit of the Indonesian nation so that it becomes a bright way to achieve the goals of a just and humane state. The second, sociologically, this update is in accordance with the development and needs of the community (in the industrial space 4.0, society 5.0, and the era of the covid-19 pandemic) and is a solution to problems in the life of society and the state. The third, juridically, it can fill the legal vacuum, codification and unification of civil procedural law will not hinder civil law enforcement and will be relevant to the principles of simple, fast, and low-cost justice.

\section{CONCLUSION}

Civil procedural law which still uses the provisions of the Dutch heritage at this time contains problematic gaps from philosophical, sociological, and juridical aspects. This legal provision is no longer in accordance with the views and spirit of the nation. The development of society, which is in the flow of industry 4.0, society, and in the era of the massive COVID-19 pandemic, is currently increasing the space to seek legal reform. This is coupled with the juridical aspect that the provisions of civil procedural law are still regulated in a scattered manner, there are laws, and give rise to multiple interpretations. This has an impact on not being implemented as a simple, fast, and low-cost trial that will be applied to the snatching of justice for justice seekers. There needs to be a civil procedural law that is in line with national development. The legal reform takes into account 
the national legal system, principles, and content material in its formation. The goal is to be codified with a unification nature that regulates the provisions of civil procedures as a whole so that the realization of a legal product that is just and humane.

\section{ACKNOWLEDGMENTS}

The authors would like to thank Allah SWT, family, friends, friends from the eighth class Faculty of Law at the State University of Semarang class of 2019, and Dr Rodiyah S.Pd, S.H., M.Si as the dean of the Faculty of Law at the State University of Semarang.

\section{DECLARATION OF CONFLICTING INTERESTS}

None

\section{FUNDING INFORMATION}

None

\section{REFERENCE}

Aidi, Z. Implementasi E-Court Dalam Mewujudkan Penyelesaian Perkara Perdata Yang Efektif dan Efisien. Jurnal Masalah-Masalah Hukum Universitas Diponegoro. (p-ISSN: 2086-2695, e-ISSN: 2527-4716).

Ansori, L. (2017). Reformasi Penegakan Hukum Perspektif Hukum Progresif. Jurnal Yuridis, 4(2), 150.

Aristeus, S. (2020). Eksekusi Ideal Perkara Perdata Berdasarkan Asas Keadilan Korelasinya Dalam Upaya Mewujudkan Peradilan Sederhana, Cepat, dan Biaya Ringan, Jurnal Penelitian Hukum De Jure, 20(3).

A. Tauda, G. (2018). Pemaknaan Pancasila Sebagai Norma Fundamental Negara. Jurnal Penelitian Humano, 9(2).

Basah, S. (1989). Hukum Acara Pengadilan Dalam Lingkungan Peradilan Administrasi (HAPLA). Jakarta: Rajawali Pers.

C. M. Ferreira, S. Serpa. (2018). Society 5.0 and Social Development Contribution to a Discussion, Sciedu Press.

Erwin, M. (2012). Filsafat Hukum. Jakarta: Raja Grafindo.

Friedman, L. (1975). The Legal System, Asocial Science Perspective. New York: Russel Sage Foundation.

G. Pereira, A, M. Lima, T dan Charrua Santos, F. (2020). Industry 4.0 and Society 5.0: Opportunities and Threats, International Journal of Recent Technology and Engineering (IJRTE), 8(5). 
G. Alam, T Achmad L. N. Antony, et al. (2019). Revolusi Industri Keempat: Akhir dari Buruh di Seluruh Dunia. Jurnal Hubungan Internasional. (2).

Guan, Y dan Eni Oktaviani. (2021). Meningkatkan Efisiensi Peradilan Dalam Tata Cara Prosedural Litigasi Perdata Indonesia. Jurnal Ilmu Hukum, $6(2)$.

Hakim, F. L. (2019). Simplikasi Prosedur dengan Pemanfaatan Teknologi dalam Rancangan Undang-Undang Hukum Acara Perdata, Jurnal Hukum Acara Perdata (Adhaper), 5(1).

Halida Zia, Mario Agusta, dan Desy Afriyanti. (2020). Pengetahuan Hukum Tentang Hukum Acara Perdata. Rio Law Jurnal, 1(2).

Hidayat, E. (2016). Perlindungan Hak Asasi Manusia Dalam Negara Hukum Indonesia, Jurnal Hukum Ekonomi Syariah, 8(2).

Hitachi-Utokyo Laboratory, Society 5.0 A People-centric Super-smart Society, Tokyo: Hitachi and The University of Tokyo.

Hudawati, S. N. (2020). Problematika Hukum Formil Penyelesaian Sengketa Ekonomi Syariah di Pengadilan Agama. Jurnal Penegakan Hukum dan Keadilan, 1(1), 29.

Juanda, E. (2017). Penalaran Hukum (Legal Reasoning). Jurnal Universitas Galuh, $5(1)$.

Kamil Ardiansyah, M. (2020). Pembaruan Hukum Oleh Mahkamah Agung Dalam Mengisi Kekosongan Hukum Acara Perdata di Indonesia, Jurnal Ilmiah Kebijakan Hukum, 14(2).

Kementerian PPN/Bappenas. (2019). Rancangan Teknokratik Rencana Pembangunan Jangka Menengah Nasional 2020-2024. Jakarta: Kementerian PPN/Bappenas.

Kusuma Fitriana, M. (2015). Peranan Politik Hukum Dalam Pembentukan Peraturan Perundang-Undangan di Indonesia Sebagai Sarana Mewujudkan Tujuan Negara. Jurnal Legislasi Indonesia, 12(2).

L. Tanya, B. (2012). Teori Hukum, Cetakan Ketiga. Yogyakarta: Genta Publishing.

L. Tanya, B., et al. (2013). Teori Hukum: Strategi Tertib Manusia Lintas Ruang dan Generasi. Yogyakarta: Genta Publising.

Latifiani, D. (2021). Human Attitude and Technology: Analyzing a Legal Culture on Electronic Court System in Indonesia (Case of Religious Court). Journal of Indonesian Legal Studies, 6(1).

Latifiani, D. (2015). Permasalahan Pelaksanaan Putusan Hakim, Jurnal HAPER, 1(1), 16.

M. Hermann, T. Pentek, B. Otto. (2016). Design Principles for Industrie 4.0 Scenarios, $49^{\text {th }}$ Hawaii International Conference on System Sciences. 
M. Wantu, F. (2015). Pengantar Ilmu Hukum. Gorontalo: UNG Press.

Mahkamah Agung RI. (2021). "Sistem Informasi Penelusuran Perkara Pengadilan Negeri Semarang". PN-Semarang, October 1, 2021, accessed from https://sipp.pn-semarangkota.go.id/.

Martiana, N. (2018). Badan Pemeriksa Keuangan dan Kesejahteraan Rakyat. Jurnal Ilmiah Akuntansi Indonesia, 3(2), 1.

Marzuki, P. M. (2011). Penelitian Hukum. Jakarta: Kencana.

Mertokusumo, S. (2011). Pengantar Ilmu Hukum. Yogyakarta: Liberty, Permadi Purbacaraka.

Mertokusumo, S. (2011). Hukum Acara Perdata Indonesia. Yogyakarta: Liberty.

Nyoman, I. K. T., Martiana, A., et al. (2015). Penerapan Teori Hukum Pembangunan Dalam Mewujudkan Peradilan Sederhana, Cepat, dan Biaya Murah. Jurnal Hukum Acara Perdata ADHAPER, 1(1).

Nyoman, R. A. P. D. (2018). Asas Integrasi Dalam Undang-Undang Kepailitan Versus Cita-Cita Kodifikasi Dan Unifikasi Hukum Acara Perdata. Jurnal Hukum Acara Perdata, 4(1).

Prodjodikoro, W. (1975). Hukum Acara Perdata di Indonesia. Bandung: Sumur Bandung.

Rahman A. \& Heriyanto. (2021). Memasyarakatkan Hukum: Pembaharuan Hukum Yang Dinamis Guna Mewujudkan Efektivitas Penegakan Hukum Yang Berkeadilan. Jurnal Hukum HUKMY, 1(1).

Ratna Sumirat, I. (2020). Penegakan Hukum dan Keadilan Dalam Bingkai Moralitas. Jurnal Hukum dan Politik Al Qisthas, 11(2).

Riyanto, R. B. Materi Diskusi Publik Pembaharuan Hukum Acara Perdata Indonesia, Badan Pembinaan Hukum Nasional Kementerian Hukum dan Hak Asasi Manusia.

Republic of Indonesia. (2011). Law Number 12 of 2011 concerning the Establishment of Legislation. State Gazette of the Republic of Indonesia Number 82 of 2011.

Republic of Indonesia. (2007). Law Number 17 of 2007 concerning the National Long-Term Development Plan for 2005-2025. State Gazette of the Republic of Indonesia Number 33 of 2007.

Republic of Indonesia. (2004). Law Number 25 of 2004 concerning the National Development Planning System. State Gazette of the Republic of Indonesia Number 104 of 2004.

Republic of Indonesia. (2020). Presidential Regulation Number 18 of 2020 concerning the National Medium-Term Development Plan for 20202024. 
Republic of Indonesia. (2020). Attachment to Presidential Regulation Number 18 of 2020 concerning the 2020-2024 National Mid-Term Development Plan.

Republic of Indonesia. (2015). Presidential Regulation Number 2 of 2015 concerning the 2015-2019 National Medium-Term Development Plan.

Republic of Indonesia. (2019). Supreme Court Regulation Number 1 of 2019 concerning Electronic Case Administration and Trial.

Republic of Indonesia. (2019). Supreme Court Regulation Number 4 of 2019 concerning Small Claim Court.

Republic of Indonesia. (2015). Regulation of the Supreme Court Number 2 of 2015 concerning Procedures for Settlement of Small Claim Court.

Republic of Indonesia. (2002). Regulation of the Supreme Court Number 1 of 2002 concerning the Procedure for Class Representation Lawsuits.

Republic of Indonesia. (2019). Decree of the House of Representatives of the Republic of Indonesia Number 19/DPR RI/I/2018-2019 concerning the National Legislation Program for the 2019 Priority Bills and Changes in the National Legislation Program for the 2015-2019 Draft Laws.

Republic of Indonesia. (2021). Decree of the House of Representatives of the Republic of Indonesia Number 1/DPR RI/IV/2020-2021 concerning the National Legislation Program for the 2021 Priority Laws and the National Legislation Program for the Amendment Laws for 2020-2024.

Ridwansyah, M. (2016). Mewujudkan Keadilan, Kepastian, dan Kemanfaatan Hukum dalam Qanun Bendera dan Lambang Aceh. Jurnal Konstitusi, 13(2).

Sayuti. (2011). Konsep Rechstaat Dalam Negara Hukum Indonesia (Kajian Terhadap Pendapat Azhari). Jurnal Kajian Ekonomi Islam dan Kemasyarakatan, 4(2).

Simatupang, Taufik H. (2019). Mendudukkan Konsep Executive Review Dalam Sistem Hukum Ketatanegaraan Indonesia. Jurnal Penelitian Hukum De Jure, 19(2), 219.

Sudjana. (2019). Penerapan Sistem Hukum Menurut Lawrence W Friedman Terhadap Efektivitas Perlindungan Desain Tata Letak Sirkuit Terpadu Berdasarkan Undang-Undang Nomor 32 Tahun 2000. Jurnal Hukum Ekonomi Syariah, 2(1).

Supomo. (1985). Hukum Acara Perdata Pengadilan Negeri. Jakarta: Pradnya Paramita.

Suriani dan Ismail. (2020). Pengaruh Pandemi Covid-19 Terhadap Pelaksanaan Persidangan Perkara Pidana di Pengadilan. Prosiding Seminar Nasional Multidisiplin Ilmu Universitas Asahan ke-4 Tahun 2020. 
Syaukani, I and Thohari, A. (2006). Dasar-Dasar Politik Hukum. Jakarta: Raja Grafindo Persada.

U. Dombrowski, T. Richter, P. Krenkel. (2017). Interdependencies of Industrie 4.0 $\mathcal{E}$ Lean Production Systems - a use case analysis, 27th International Conference on Flexible Automation and Intelligent Manufacturing, FAIM2017, Italy.

Widagdo Eddyono, L. (2010). Penyelesaian Sengketa Kewenangan Lembaga Negara oleh Mahkamah Konstitusi, Jurnal Konstitusi, 7(3).

Yonas Bo'a, F. (2018). Pancasila Sebagai Sumber Hukum dalam Sistem Hukum Nasional. Jurnal Konstitusi, 15(1).

Yuniwati. (2017). Politik Hukum dalam Kesejahteraan Rakyat. Jurnal Justicia Sains, 2(2). 


\section{ABOUT AUTHOR(S)}

Ahmad Habib Alfikry is a 5th semester student with a concentration in private commercial law, Faculty of Law, State University of Semarang. Born in Pemalang, May 1, 2000. This man is active in several student activities such as Lex Scientia (served as Head of the Research and Scientific Work Division until now) and the Moot Court Unit (served as Staff of the Competition Division until now) Faculty of Law, State University of Semarang. His writing experience is like the article: (i) "Hukuman Kebiri Kimia Bagi Pelaku Kekerasan Seksual Terhadap Anak Dalam Perspektif Hukum Islam" in the Law Journal Lex Generalis; (ii) "Ekuilibrium Pengaturan Perlindungan Data Pribadi Sebagai Jaminan Hak Konstitusional Refleksi Implementasi di Masa Pandemi Covid19". Moreover, there are opinions published online on legal platforms: (i) "Urgensi RUU Masyarakat Adat untuk Masa Depan"; (ii) "Hubungan Hukum dan Stratifikasi Sosial dalam Kajian Sosiologi Hukum"; (iii) "Quo Vadis Hukum Pidana Indonesia"; and (iv) "Hukuman Mati Koruptor: Merenggut Right to Life Refleksi Summum Jus Summa Injuria".

Muhamad Riyan Afandi is a 5th semester student with a concentration on constitutional law, Faculty of Law, State University of Semarang. Born in Pemalang, October 1st, 2001. This man is active in several student activities such as GMPI (Student Movement for Science Corner) within the Ministry of Communication and Information.

Dian Latifiani, S.H., M.H. was born in Semarang. She is a civil servant lecturer at the Faculty of Law, State University of Semarang. Her expertise is civil law, especially civil procedural law and civil court practice. The last education is Magister of Law. There are several publications such as: (i) Mediasi sebagai alternatif penyelesaian sengketa dalam perkara perdata (Tinjauan menurut PERMA No. 01 Tahun 2008); (ii) Principles of islamic agreement in preparation of deed; (iii) Pernikahan dini di Indonesia: faktor dan peran pemerintah (Perspektif penegakan dan perlindungan hukum bagi anak); and others. 